\title{
A quest for the atgeir: the unknown Viking weapon in Icelandic sagas and archaeological data
}

\author{
Yulia Shtyryakova, \\ independent scholar, \\ yulya23@gmail.com
}

\begin{abstract}
Today we know much about the culture of the Viking Age, but there are still gaps to fill. One of them is what the legendary weapon called atgeirr in Icelandic sagas really was. Nowadays researchers prefer to view atgeir as a kind of spear. But the defining features of atgeir are not clearly described and the range of different kinds of spearheads suggested as related to this weapon is frustratingly wide.
\end{abstract}

This paper draws on saga material with the aim to describe essential characteristics of atgeir which differentiate it from the spear. This would allow to considerably narrow down the list of proposed candidates for the role of atgeir among archaeological finds from the Viking Age and to recognise it as a special type of weapon, just as it is referred to in Icelandic sagas

Keywords - atgeir; Viking spear; Viking Age; polearms; Viking halberd

\section{INTRODUCTION}

The Viking Age has for many years continued to be of great interest for both researchers and history enthusiasts. And one of the things essential to the Viking culture is weaponry. When it comes to the Viking weapon one can say we know much about it, because in addition to archaeological data we have written sources such as Old Icelandic sagas that describes the life of Viking Age people in vivid details. But sometimes combining these sources could lead not to enlightning, but to confusion. The long standing problem of atgeir could be a good example of this.

While spears are the only type of polearms known to the Vikings, Icelandic sagas say that where was another pole-weapon - atgeir (atgeirr).

Sagas mention atgeir from time to time, never describing it in detail. Among other unindentified Viking weapons the atgeir is of the most interest for researchers, being the favourite weapon of one of the protagonists of the most popular and the most studied of sagas of Icelanders - the Njáls saga.

According to sagas, atgeir is definitely a pole-weapon. The way the term atgeirr is used in Old Icelandic texts leaves no doubt that atgeir was considered a special type of weapon and not a variety of some other weapon. The term is used as consistently as "sword" or "axe" and is never substituted by a synonym. Therefore, suggestions were made that atgeir was of the same nature as halberd and glaive. Still, there were no objects among 
archaeological finds of the Viking Age which could not be attributed to known types of Viking weaponry: spears, swords, axes, etc.

An Icelandic-English dictionary by Richard Cleasby and Gudbrand Vigfusson considers the atgeir "undoubtedly a foreign weapon"1 and recommends translation as "halberd" or "bill".

It seems the researchers currently do not have convincing hypotheses for what the atgeir was. Moreover, it has acquired a reputation of an insolvable enigma. Even Jan H Orkisz, who in his paper "Pole-weapons in the Sagas of Icelanders: a comparison of literary and archaeological sources" made reasonable assumptions about other types of unknown weapons mentioned in sagas, says that it is "difficult to give an assertive conclusion" 2 on the nature of the atgeir.

\section{THE GOAL AND METHODOLOGY}

The goal of this paper is to identify the weapon that was called atgeir in the Northern Europe of the Viking Age by using the only source of information about it — Old Icelandic sagas. We will attempt to describe the key features of this weapon, the way it was used and any other data that could help to understand its nature. Then we will try to find the items with matching properties among known archaeological evidence of the Viking Age.

Since previous attempts to recreate the appearance of the atgeir using information from Icelandic sagas were unsuccessful, in this paper we attempt to examine every aspect of data concerning the atgeir (such as where it could be found, who owned it, etc.) in order to maximise the amount of material to analyse.

The original texts of Old Icelandic sagas and skaldic poetry were used as primary sources for analysis, because in translations the details about this unknown weapon as well as its name are frequently changed according to translator's opinions.

The main assumption this paper is based on is that the atgeir existed in Scandinavia of the Viking Age. While it is common among saga researchers to consider the atgeir an anachronism and attribute it to the times of saga authors (13th -14th centuries AD) and not saga characters (9th -10 th centuries $A D$ ), we are inclined to consider such a conclusion premature in absence of solid evidence. Therefore, the finds of the Viking Age weaponry in Scandinavia (taken from the works by researchers such as J.Petersen along with digital museum collections freely available online) are used as archaeological evidence.

\footnotetext{
${ }^{1}$ Cleasby, Vigfusson, An Icelandic-English Dictionary, p. 30

2 Orkisz, "Pole-weapons in the Sagas of Icelanders", p. 192 


\section{THE VIKING SPEAR}

Before delving into analysis of Old Icelandic sources, it is necessary to clarify some of the terms important for further understanding. Together with the majority of modern-day researchers, we are inclined to see the atgeir as a spear-like weapon. Therefore a more thorough look at the Viking spears is required.

Everyone has a notion of what the spear is, but is this basic knowledge enough to confidently judge about polearms of the vikings?

The spear was the most widely used weapon in the Viking Age, as confirmed by archaeological data and textual sources. It was easy to make and very effective weapon, so every warrior carried a spear. Sagas inform us that swords and axes were mostly used as an addition to spears.

The main parts of a spearhead are shown in Figure 1. It should be noted that the term "spear" (spjót) in Old Icelandic mostly means "spearhead" and not the whole weapon with its shaft. A spear (i.e. a spearhead) consisted of a blade (fjö̈r, literally "feather") and a socket (falr) — the part used to fix the blade on the shaft.

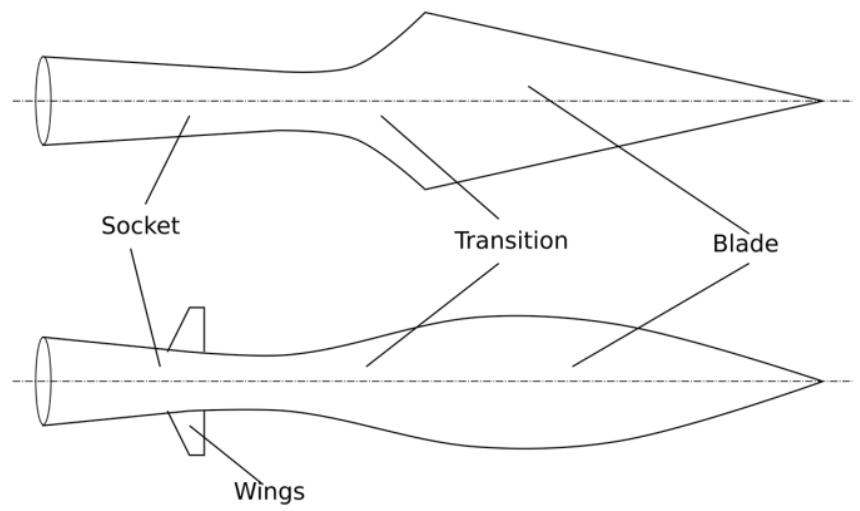

Figure 1: Main parts of the spearhead. (C) author.

Blades varied widely in size and forms, but they were always double edged and symmetrical. Often below the blade there were so called "wings", which are believed to prevent the spearhead from penetrating the body too deeply.

Spear shafts were as long as human height or longer, but certain accounts from sagas lead to conclusion that the length equal to the height of a human with a raised hand was considered a bit too long. ${ }^{3}$ The length limit was determined by the use: the Vikings always fought on foot therefore their spears could not be very long. The shaft diameter of the majority of discovered spears varies from 2 to $3 \mathrm{~cm}$.

Many different types of spears are known to us from archeological finds. The sagas name some of them, e.g. broddspjót ("pike"), fjadraspjót ("feather-shaped spear"), krókaspjót 
("hooked spear"). The wide variety of spearhead forms and sizes is reflected in an Old Icelandic saying: Erat audskept almanna spjör (It's not easy to make a spear for everyone, i.e. to please everyone at once).
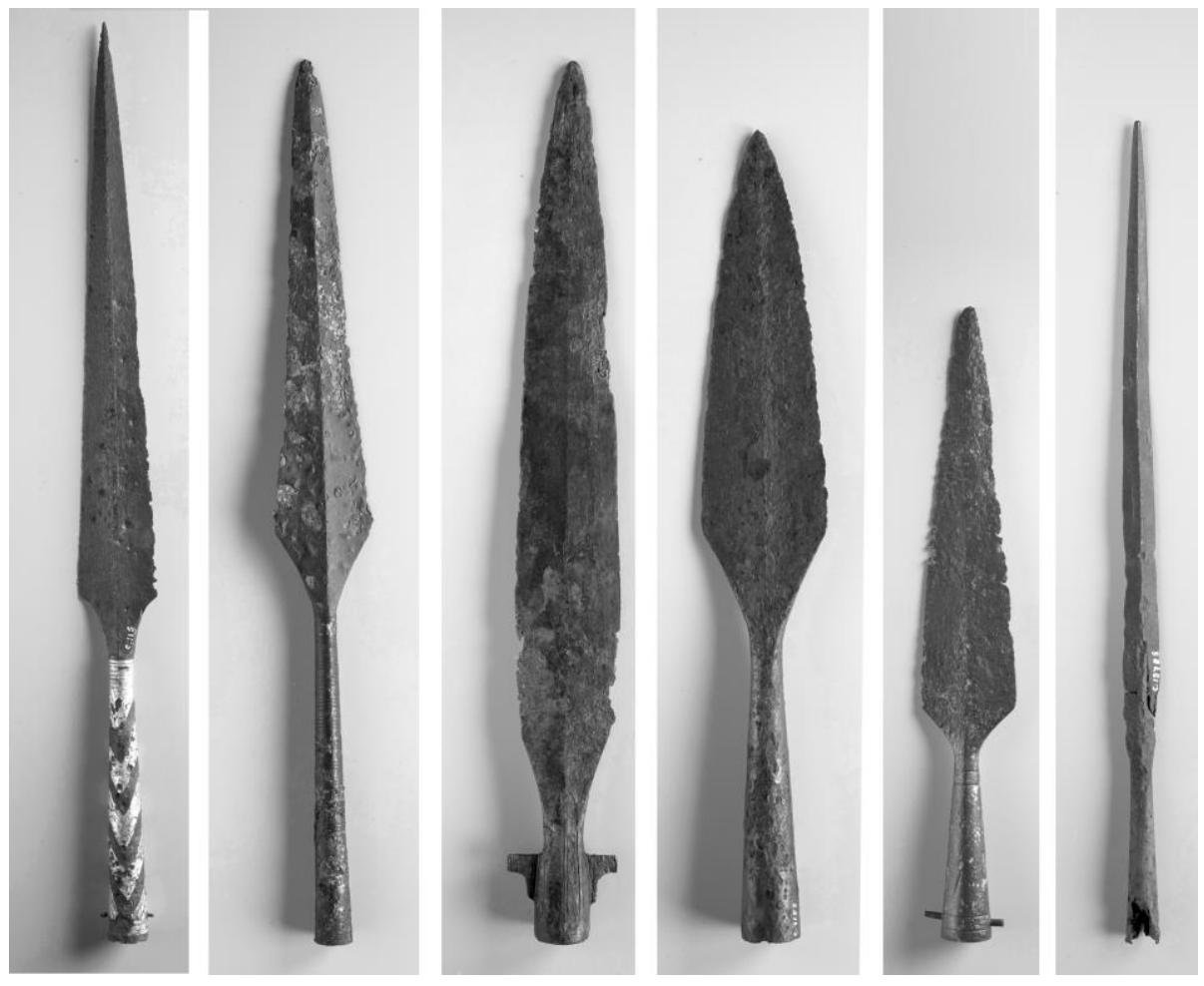

Figure 2: Viking Age spearheads from the online collection of Kulturbistorisk museum, UiO (Norway). From left to right: museum number C115, C13948, C30253, C7155, C26494b, C15785, photographer: Helgeland, Kirsten. / License: CC BY-SA 4.0

Since both the spearhead and the shaft could be self made, a warriors chose the most fitting variant for their needs, still all these weapons were classified as spears. However, the atgeir is never called a spear (spjót) throughout Old Icelandic texts.

According to sagas, spears were mainly used for thrusting and less frequently for throwing. Mostly, warrior held it in one hand, having shield in another, but two-hand grip could also be used if needed.

This is the short description of the most popular Viking Age pole-weapon — the spear. Now it is time to consider the atgeir and everything we know about it from Old Icelandic sources. 


\section{ANALYSIS OF WRITTEN SOURCES}

\section{IV.1. Some notes on etymology}

The suggestion that the atgeir is a kind of spear originates from its name, which is derived from geirr. In Old Icelandic geirr is a beiti (a poetical synonym) of a spear, used, along with other heitis for spear (vigr, darr, etc.) only in poetry, or personal names, or toponyms. In prosaic texts spear is always called spjót. It seems that the reason is purely stylistical, with poetry being strictly "high style" while prose could be composed using regular language. Not observing the style would lead to negative appreciation of the work by the audience.

Practically the only example of the word geirr used in prosaic text is found in Völsunga saga, a re-telling of the poetic verses from The Old Edda concerning Sigurd the Dragon Slayer. This is how saga describes the death of Sigurd's father Sigmund:

When the battle lasted for some time, a man in a hat and a blue cape appeared on the battlefield. He was one-eyed and had a spear [= geirn] in his hand. He approached Sigmund konung and raised his spear before him. Sigmund struck him with his sword and the sword, meeting the spear, broke in two. (cf App. 1).

It can be guessed that the "man in blue cape" was Odin himself, who has come to take Sigmund to Valhalla. The geirr in his hand is the legendary spear Gungnir, the only spear that deserved to be called geirr while the spears of mere mortals were always called spjót in sagas.

As it was mentioned previously, the names of the spearheads reflect their form. If the geirr means spear, then what at means? The first part of the word atgeirr is rather hard to interpret.

Jan Orkisz suggests in his paper that at brings the meaning related to fighting and therefore translates atgeirr as "a battle spear" in contrast to e.g. hunting spear. The Cleasby\&Vigfusson dictionary indeed has "clash" as a rare meaning of the word at. But this explanation seems to be doubtful, because at in the above-mentioned meaning was not used for word formation. In most Old Icelandic words beginning with at, this is a prefix denoting the direction of action: "towards", "to", etc. Some of these words actually refer to fighting, for example atsókn - "onslaught, attack" (derived from sakja at - "to attack somebody"), or atgangr - "fighting, combat" (derived from ganga at - "to go to somebody"), but where are also many examples that do not: athugi - "attention, care" (derived from byggja at - "to think about somebody") or atkváma - "arrival" (from kváma at - "to arrive to somewhere").

Therefore it seems that the word atgeirr has no direct meaning in Old Icelandic. It is known that similar words existed in Germanic languages before the Viking Age: OHG. aziger, OFris. etger, MHG. atiger, etc. They are derived from Germanic root gar (spear) and are believed to signify a type of a spear. ${ }^{4}$

${ }^{4}$ Keller, The Anglo-Saxon Weapon Names, p. 131. 
But the main puzzle is that the atgeir is never called a spear (spjót) in Old Icelandic sources. Therefore, we are forced to conclude that saga authors did not consider the atgeir a type of spear.

\section{IV.2. Old Icelandic Sagas}

The atgeir is mentioned in the sagas of Icelanders, most importantly, in the Njáls saga, as well as in the legendary sagas and skaldic poetry. Further on in this paper we will attempt to identify the key features of this weapon and its usage. Also we will try to affirm if saga authors themselves knew what the atgeir was, or they used this word symbolically without attaching the precise meaning to it. Reasonable assumptions about this could be made based on the extent to which the descriptions from different sources consistent and uncontradictory. It is also important to ascertain that this word always signifies the same weapon, because the timespan of references to the atgeir in Old Icelandic literature ranges from $10^{\text {th }}$ to $14^{\text {th }}$ century AD. Should it not be so, we will be forced to admit that it is impossible to define the atgeir. Along with the descriptions of the atgeir and its usage we will consider the context - historical, geographical, etc., in which it appears.

All quotes below are given in my own translation concentrated mainly on accurate rendition of the details of battle descriptions which are very specific in sagas. In most cases the way a weapon is used is clear from the terms used. For example: leggja - "to thrust", böggva - "to hew", ljósta - "to strike bluntly", skjóta - "to throw" (of a spear). The general term vega - "to fight with a weapon" - is used rarely.

The available sources are divided into groups according to saga types (moving from fantasy stories towards realistic ones) and characters who use an atgeir.

\section{IV.3. Legendary sagas}

Given that legendary sagas are fantastic stories one might think that they cannot be used as the source for scientific research. But considering that overall the number of references to atgeir in sagas is small, we cannot refuse to take them into account. The plots are based on historical events of ancient times and the characters in many cases have historical prototypes. Most importantly, descriptions of everyday life and of the battles, though at times exaggerated, are realistic on the whole.

\section{IV.3.1. Giants and Trolls}

In Sturlangs saga starfsama the protagonist receives from a giantess a magical weapon - an atgeir that could become small as a hairpin and then return to the normal size by the wish of its owner. Later in the saga Sturlaug uses it against the same giantess, who threatens to kill his friend. He uses it like a spear: "Sturlaug thrust her with the atgeir and pierced her through" (App. 2). This atgeir could also cut stones.

Illuga saga Tagldarbana is known to be recorded considerably late, in the 17th century. But it is a very interesting fact that the description of the atgeir in it fully conforms to the sagas which are more close to the Viking Age. This comes in contrast with a popular 
belief that later in time the word atgeirr in Icelandic has assumed the meaning "halberd". The extract below shows that Illugi's atgeir does not resemble a halberd.

The saga says that Illugi received gifts from Aðalrád the King of England. Among them was an atgeir, an excellent weapon. The king told Illugi that he would never fall in battle as long as he had it with him. Illugi always fought with this atgeir until he broke it piercing a troll.

Illugi also uses the atgeir in the same way as a spear: "As for Illugi, as soon as he came in, he thrust the atgeir with two hands in Tjosni stomack and pierced him through" (App. 3). Or "Illugi came to him and thrust his atgeir into jotun so hard that it broke above the socket" (App. 4).

The latter extract is very interesting because it gives a construction detail of the atgeir: just like a spear it is mounted on a shaft by means of a socket.

\section{IV.3.2. Warriors from Gardariki}

In Göngu-Hrólfs saga the atgeir is mentioned in two episodes. In the first episode Hrolf, the protagonist, had to fight with two vikings, Tryggvi and Vazi. The sea fight described had taken place near Jutland in Denmark (Jótland).

Hrolf fights Vazi whom the saga describes as follows: "He was a sheer troll [i.e. a giant] by height and strength" (App. 5). Vazi is armed with an atgeir, and Hrolf with a spear: "The atgeir came into Hrolf's shield and split it in two, but Hrolf was not wounded" (App. 6).

After that Vazi splits the shaft of Hrolf's spear in two with his atgeir and Hrolf breaks the atgeir's shaft (the saga notes Hrolf's prodigious strength). The two opponents fight unarmed for a long time and Hrolf eventually wins.

Next time Hrolf fights an atgeir wielder somewhere in the Southern territories of Gardariki (Kievan Rus'). His name is Sóti and he is a chieftain of a squad guarding a borderline island between Gardariki and Tattarariki (the Golden Horde lands). The saga says that Sóti's mother was from Tattarariki and his father was from Holmgardariki (Novgorod region). "He was a sheer troll by his height and strength" (App. 7).

"Sóti had an atgeir and he alternately hewed or thrusted" (App. 8). The opponents fight on horseback. Sóti tries to pierce Hrolf with his atgeir and then splits his shield together with his horse in two in one blow. The opponents then fight on foot and Sóti again tries to cut Hrolf, who dodges, and the atgeir dives deep into the earth (App. 9). Hrolf uses his chance and kills Sóti.

A battle between Vikar konung and Sisar konung is described in Gautrek's Saga (Gautreks saga). The battle takes place in Southern Sweden, in Götaland (Gautland). "He [Sisar] was from Kanugard [Kiev]. He was a great champion and had a big army with him" (App. 10).

Sisar fights in the forefront of his men and he is armed with an atgeir and a sword. Legendary hero Starkad meets him in a fight and suffers great damage. Sisar wounded him many times with heavy wounds, each one of them sufficient to kill an ordinary man, but Starkad only 
recites the list of his injuries in poetic verses. The following is said about the atgeir: “...and in my other side he thrust an atgeir so that the full blade came in" (App. 11).

\section{IV.3.3. Vikings}

The atgeir is briefly mentioned in Saga of Bósi and Herraud (Bósa saga ok Herraujs): "Herraud turned to Siggeir and thrust him with an atgeir so that it came into the shield. Siggeir turned his shield with great force so that Herraud released the atgeir" (App. 12).

In the following episode from Hálfdanar saga Eysteinssonar the protagonist meets the ships of the ruthless viking Ulfkel in a sea fight. The situation is difficult for Halfdan's men due to the forces are unequal. Suddenly fifteen ships arrive on the scene and their leader, a very tall warrior, offers help to Halfdan and joins the fight. He is armed with a sword and an atgeir. Putting Ulfkel flying he then turns to Ulfkel's trusted companion Hrafnkel. It should be noted that the atgeir and kesja are mentioned together in this scene: "Hrafnkel threw two kesja at once at the tall man and he took both in flight and threw them back, and each hit a man. Then he pierced Hrafnkel's shield and his arm with the atgeir, lifted him in the air and hurled him into the sea" (App. 13).

In this episode a very characteristic technique of using an atgeir is introduced — lifting of the pierced enemy into the air. It will be featured in several other examples further in this paper. Also, the following detail needs to be noted. The quotation above is usually translated as "pierced the shield and two arms" (i gegnum skjöldinn ok báda handleggina). But the shield is generally held by one hand and it is hard to imagine a thrust in a shield that could damage two hands at once. It is more correct in my opinion to consider that the word handleggr here means the parts of the arm: forearm and upper arm. Therefore the situation could be reconstructed in the following way: a strong thrust into the shield brings it close to a man; the arm holding the shield bends in the elbow and the blade goes through the shield, the forearm and upper arm. From this description not only can we see the great penetrating ability of an atgeir, but also the length of its blade that could pierce both the shield and a folded arm.

The events of Hálfdanar saga take place in Northern territories of Rus', and the place of the battle described above is located by the researchers in a region of Ladoga Lake or Onega Lake.

Finally, the weapon named arngeirr is mentioned in Hjálmpés saga ok Ölvis. It belongs to Tóki, the viking chieftain and the enemy of the saga's main characters: "Tóki rushed forward bravely. He had a big and stout arngeirr in his hand. Soon he killed thirty men" (App. 14). When Ölvir sees that he jumps to Tóki“s ship. "Tóki took the arngeirr with two hands, pierced through Ölvir's shield together with his arm [see above], lifted him into the air and hurled him down to the deck so that he lost consciousness" (App. 15). The full match of this description with the description above leaves no doubt that arngeirr is the same as the atgeir.

The consistent appearance of the atgeir as the weapon of the vikings in written sources is also illustrated by the Old Norse Konungs skuggsjá, "A King's Mirror", written in 1250. It mentions the atgeir among weapons suitable for naval battles (App. 16). 


\section{IV.3.4. Preliminary Conclusions}

At this point the following conclusions can be made:

- First of all, without a doubt the authors of the legendary sagas had a clear understanding of the nature of the atgeir. This is confirmed by consistency of its description in all the sources considered in this paper.

- Saga authors never substitute the term atgeir with a spear or a kesja. These are definitely different kinds of weapons, as could be seen from the episodes where opponents use them together.

- It can be assumed that the atgeir is a big and heavy weapon. Warriors who use it are mostly described as persons of unusual strength.

- The atgeir is suitable for hewing, but most frequently it is used like a spear. When thrusted through a shield it can split it which suggests a considerable width and thickness of its blade.

- The atgeir is a prestigious weapon. It is mentioned in magical context more often than any other weapon. All of atgeir wielders in legendary sagas (except fictional creatures) are not ordinary warriors, but chieftains. This fact points to the air of distinction that this weapon has in the eyes of saga authors and their audience. It is also interesting to note that in most cases the atgeir wielders come as opponents to sagas protagonists who have more traditional weapons. Although these characters also have Scandinavian names, it might be taken as an indication of the fact that the atgeir was a foreign weapon to the Norwegians and the Icelanders of the Viking Age, with which the majority of researchers agrees.

- Lastly, the atgeir is clearly connected with the Eastern Way (Austrvegr). It is on the Eastern Way where most episodes featuring the atgeir take place. Geographical context of atgeir descriptions in sagas is limited to Southern Sweden, the Baltic Sea Region and Gardariki. The atgeir does not appear in the sagas of viking raids to the West. (We could also mention here that it was on the Eastern Way where Gunnar Hámundarson obtained his famous atgeir).

The next part of the paper looks at the sagas of Icelanders. Although the Njáls saga is undoubtedly the main source of information about the atgeir, it is mentioned in several other sagas as well, leading us to the conclusion that Gunnar's atgeir was not the only of its kind in Iceland.

\section{IV.4. Sagas of Icelanders}

In Dáttr Dorleifs jarlaskálds the protagonist was killed with an atgeir that his murderer sent by Earl Hakon brought from Norway (App. 17). This atgeir previously belonged to the pagan deity Hörgi.

In Eyrbyggja saga Snorry Godi's enemies promise freedom to a slave Svartr the Strong if he kills Snorry with an atgeir from an ambush on the attic of Snorry's house. They tell him to thrust Snorry when he comes in, "so that blade goes into him from the back and goes out from the stomach" (App. 18). 
In Laxdaela saga one of the characters, twelve years old Hardbein Helgason, pierces with an atgeir a steel helmet on the head of his opponent (App. 19).

Another reference to using an atgeir in a fight can be found in Landnámabók: "When Thorbjörn wanted to close the fortification he was pierced through with an atgeir. $\mathrm{He}$ takes it from his wound and set in the back of Jörund, so the blade came out from his breast" (App. 20).

In all of the cases above the word "atgeir" is used without any clarifications or hints at the uniqueness of this weapon, just like the name of any other customary weapon. Therefore, we can say that the atgeir was familiar to Icelanders and existed in Iceland, though in small quantities. On the one hand its rarity comes in accordance with the suggestion that it was a foreign weapon, hard to acquire in Iceland, but could have an additional reason: it was probably unsuitable for most of fighters due to its size and heaviness.

However, there was one man in Iceland who chose the atgeir as his primary weapon. This was Gunnar Hámundarson, one of the protagonists of the Njáls saga. This saga contains many impressive descriptions of how effective the atgeir could be in the hands of a skilled warrior.

Unfortunately, the Njáls saga is often doubted by researchers as a reliable historical source. This saga is one of the latest, considered to be written in the late $13^{\text {th }}$ century. It is confirmed that its author used written sources when composing the text. Many researchers accuse the author of the shift from the oral tradition and the anachronisms in the text, considering the atgeir the main of such anachronisms. The kite shields which are believed not to exist in the Viking Age but are mentioned in the text many times could be another good example.

Still, we consider it premature to to dismiss this saga from analysis, as there is always room for misunderstanding the subject, especially when data is lacking. As it was stated previously, this work is based on assumption that the atgeir was known to the Scandinavians of the saga age, since there are no proofs to the contrary.

\section{IV.4.1. Atgeir in the Njáls saga}

As the saga says, Gunnar acquired his atgeir in a sea fight near the island of Eysýsla (modern Saaremaa in the Baltic Sea), on Austrvegr. The circumstances of its obtaining remind of the legendary sagas. A man who warned Gunnar about an upcoming viking attack tells him that the leader of these vikings, Hallgrim, has an atgeir, "the weapon that has no equal", and could not be killed with another weapon except it. It was true. Gunnar takes this atgeir with him and it becomes his favourite weapon.

Fighting Techniques

The Njáls saga contains the most impressive examples of using an atgeir in a fight. They seem to be consistent with the information from the legendary sagas, e.g. the abovedescribed "pierce, lift and hurl down" technique: "Gunnar thrust with the atgeir to Egils 
stomach. Gunnar lifted him on the atgeir and hurled into the river" (App. 21). This technique is described in the saga three times.

The atgeir piercing through a shield and splitting it in two: "Gunnar threw the atgeir to him and hit the shield, the shield was split in two parts and atgeir pierce Önund through" (App. 22).

Besides these familiar techniques, Gunnar uses the atgeir to disarm his opponents: "Skammkel jumped behind Gunnar's back and swung with the huge axe. Gunnar quickly turned to him and strike with his atgeir under the axe's "neck", knock it out of hand and it flew into the rever" (App. 23).

This is a very good example of how realistic the fight description is. Skammkel hopes to hit Gunnar with his axe, so he is close to him and out of the range of the atgeir's blade. Moreover, he is attacking from behind, so Gunnar is unable to use the atgeir against him in the usual way. That is why, as the saga specifies, his is not a thrusting or a hewing, but a blunt strike - with the shaft or flat side of the blade (the shaft is more likely due to the short distance). It is a blow with the long heavy staff at a good speed, as Gunnar turns around to face Skammkel. In addition, the atgeir caught on the narrow part of the axe's blade, between the blade and the shaft, so it is not surprising that the axe was knocked out of the hand and flew a long way. Having Skammkel disarmed, Gunnar now has time, with the next move, to pierce him through with the atgeir, lift him into the air and cast down on the ground.

The same situation takes place in the following episode: "Berk swung to Gunnar with the sword. Gunnar strike with the atgeir so forcefully that the sword was knocked out of Berk's hand" (App. 24). Again a blunt strike, most likely with the shaft.

Gunnar holds his atgeir with one or two hands depending on the situation and sometimes uses the atgeir and the sword at the same time: "He took the atgeir and the sword and fought with two hands" (App. 25).

Lastly, sometimes Gunnar throws the atgeir, these episodes being the most impressive demonstrations of force, because the atgeir splits a shield or pierces the body through and flies further: "Sometimes later Gunnar threw the atgeir to Berk and it pierce him through and went down to the ground" (App. 26).

It is interesting to note that according to the saga Gunnar never hews with his atgeir, probably a trait of his individual fighting style. His son Högni uses the same atgeir to hew: "Hroald thrust with a spear to Högni. Högni cut the spear shaft in two with the atgeir and pierce Hroald through" (App. 27). This is the only description of using the atgeir for cutting in the sagas of Icelanders.

\section{IV.4.2. Additional information about the atgeir}

The saga also contains other facts about this weapon. When in a bad mood, Gunnar, a rather emotional and open-hearted person, did not mount his horse in the usual way, but jumped into the saddle with the help of his atgeir: "Gunnar goes out, plunges the atgeir into the ground, throws himself into the saddle and rides away" (App. 28). 
In other words, he uses the atgeir in the same way a pole vaulter uses his pole, pushing off it and lifting himself into the air. The more convenient and safe way to do it would be to plunge the atgeir into the ground blade down.

We can estimate the minimum length of the atgeir required to accomplish the jump. The shaft of the atgeir partly plunged into the ground was enough for Gunnar to take hold of its end at the level of his head or may be slightly higher. Therefore the length of the atgeir's shaft should be comparable to the length of the spear shaft - human height or longer.

Finally, the saga describes another distinctive feature of this weapon - it produces a loud sound (or "singing" as the text puts it) when the owner takes it to a fight, "predicting the death of one or many". The saga author explains it as a manifestation of the magic nature of the weapon.

At the same time there is nothing supernatural about this fact. A big blade made from high quality steel could indeed make a loud ringing sound when struck about something, being taken off the wall where it was hanging and this exactly the situation when the sound is heard (twice) in the saga. So, the reason is the construction of the blade, which is why other weapons did not make such a sound.

\section{IV.4.3. The Facts the Njáls Saga Does Not Contain}

It seems strange that the saga says absolutely nothing about the look or details of this weapon, though such information can be usually be found in sagas and in the Njáls saga one can find the descriptions of weapons belonging to other characters. The saga also does not mention if this weapon had a name, although very often weapons were given names, and this particular atgeir is viewed by the author as possessing a kind of personality.

The absence of the these details could be explained in the following way. Keeping in mind the confirmed popularity of the Njáls saga in the medieval Iceland it could be suggested that author did not include things that were known to everyone. The famous atgeir of Gunnar Hámundarson - and the atgeirs were very rare in Iceland - was known to everyone and required no descriptions. In addition, contrary to the custom, it was not put in Gunnar's burial mound so it is probable that it was available to look at at the times when saga was written.

Another possible explanation is that this atgeir had no distinguishing details. Therefore despite paying homage to this weapon the saga author did not include its description. So Gunnar's atgeir was not a unique atgeir, but a rather ordinary specimen renowned only by its loyal service to its owner in his numerous and mostly unequal fights.

\section{IV.4.4. Preliminary Conclusions}

The sagas of Icelanders do not emphasise the heaviness of atgeir. What is more, it is hard to imagine that a 12-year old teenager could effectively use such a seemingly heavy weapon as the atgeir owned by Gunnar Hámundarson.

The Njáls saga gives us more information on the subject than all other sources together. Descriptions of the atgeir usage in fighting here is more detailed than in the legendary 
sagas giving an impression that the battles were described by eyewitnesses. At the same time the descriptions are consistent with information from other sources.

The Njáls saga describes one particular atgeir, but it could be assumed with high probability that it was a typical specimen, so the information can be applied to other atgeirs too.

The favorite weapon of Gunnar Hámundarson undoubtedly resembles a spear and he uses it mostly as he would use a spear. At the same time the atgeir is more universal than a spear: it also can hew, it can be used to disarm and it can break bones - which is not typical for a spear. Also it might be longer than an ordinary spear and have a bigger blade.

\section{IV.5. Skaldic Poetry}

The atgeir is mentioned several times in skaldic verses. Of course, poetical texts should be used with caution bearing in mind the deep imagery and a tendency for generalisation peculiar to the skaldic poetry. Still in the case of weapons skalds are known to be quite specific.

Though name of any weapon type could be used as a beiti (poetical synonym) of weapon in general, then it comes to the certain thing, the visual similarities go in the first place. For example, snake or fish are used in the kennings for sword, and no skald ever use the word "axe" as a heiti for sword.

The term atgeirr is not so rare in skaldic poetry, which could be explained by the fact that it is one of a few heitis for a weapon starting with a vowel. In most cases it is used as a generalised term for a weapon in the kennings of a man. For example, atgeirs toftir - "the atgeir's places" mean "hands" in Arinbjarnarkvida by Egill Skalla-Grimsson, or atgeira éldraugr - "the log of atgeirs' storm" means "warrior" in the visa from Grettis saga.

The following two cases, however, require a more careful consideration.

Skald Thord Kolbeinsson says the following visa when going to fight his old enemy Björn:

Öllungis biðk allar, atgeirs eða goð fleiri, rétt skilk, rammar vættir randóps, pærs hlýrn skópu, at, styrbendir, standi, stálgaldrs, en ek valda, blóðugr örn of Bjarnar barðrauðr höfuðsvörðum. ${ }^{5}$

Normally this visa is interpreted in the following way: "I ask with my whole heart the mighty battle creatures, who create the Moon in the skies, and also the gods of warriors

${ }^{5}$ Bjarnar saga Hitdalakappa, ch. 30 
(hergod) that an eagle with a bloody beak stands above Björn's head because of me". ${ }^{6}$ This translation implies that the term atgeir is used as a general beiti for a weapon.

But if we suggest that atgeir here is a beiti for a spear, then instead of the vague "gods of warriors" we get the kenning "the god of the spear", i.e. Odin, which is more fitting into the context. "I ask with my whole heart the God of the spear and mighty battle creatures..." That is to say, the skald in accordance with pagan customs, asks Odin and Valkyries to grant him victory.

The following visa by Egill Skalla-Grimsson from the Egils saga can be considered the earliest mention of the atgeir in Old Icelandic literature (mid. 10 ${ }^{\text {th }}$ century AD). The events take place in Norway on the feast of the King's governor named Bard. Egill drunk more than anyone else and, accompanying his friend outside, he says to the host:

Q1 ber mér, pvít Qlvi

ol gervir nú fọlvan, atgeira lætk úra ýring of grǫn skýra;

Qllungis kant illa, oddskýs, fyr pér nýsa, rigna getr at regni regnbjóðr Háars pegna. ${ }^{7}$

Explaining the kenning with the word atgeir is not difficult here because of the evident context of the visa. Egill took a horn of beer from Bard, drunk it, then said that he "let the rain of the atgeirs of auroch (úra atgeira yring) flow down his mustache". The kenning is always translated as "the rain of auroch's spears", i.e. "the rain of horns" meaning "beer". Therefore in this case the atgeir is definitely translated as "spear".

In conclusion, despite the small amount of material to analyse, Icelandic skaldic poetry supports understanding of the atgeir as a weapon similar to a spear.

\section{IV.5.1. Preliminary Conclusions}

* There is no detailed account on the appearance or construction of the atgeir among the available literature sources. Thus we can assume that this weapon was not so rare, and the audience did not need the detailed information. The consistency of characteristics throughout the sources proves that the saga authors knew the subject quite well.

* The atgeir was a rare weapon indeed. There are much fewer references to the atgeir in the sagas than to spears, axes or swords. Also, according to the sagas, the atgeir was mostly spread on the Eastern Way (Fig.3).

${ }^{6}$ Translation to modern Icelandic by "Íslendinga sögur", Guðni Jónsson bjó til prentunar: "Eg bið af heilum hug allar máttugar orrustuvattir, par er skópu bimintunglin, og fleiri hergod, - eg skil, bvad rétt er, - að blódugur Örn standi með raudan gogg yfir höfudsvördum Bjarnar, en eg valdi (vígi hans)."

${ }^{7}$ Egils saga, ch. 44 
* The atgeir is likely to be a heavy weapon, although not all references confirm this assumption. By the effect it causes when being used in a fight we can presume it has a long, wide and thick blade, and a long and stout shaft.

* The atgeir is primarily a thrusting weapon. Although it has the ability to hew, thrusting technique prevails (see Table 1). In addition, the atgeir, like a spear, is suitable for throwing.

* With a high probability the atgeir had no constructive details to limit penetration depth.
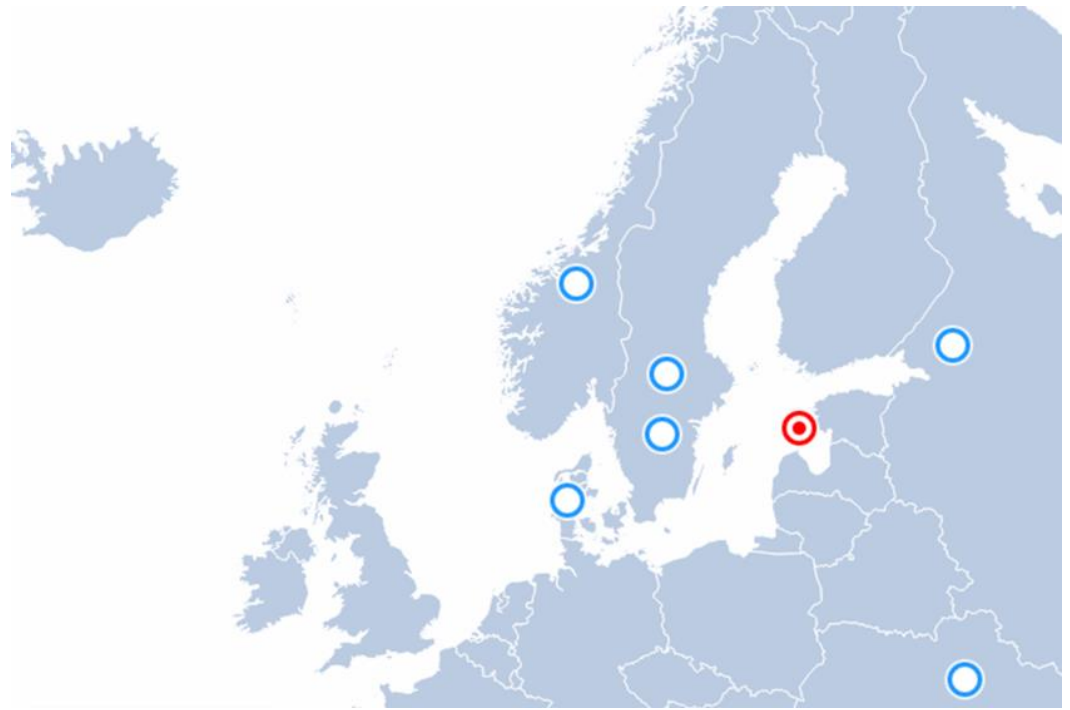

Figure 3: Geographical context of references to atgeir outside of Iceland. Red dot marks the place where atgeir was acquired by Njáls saga

Table 1 summarises the battle usage of the atgeir according to the Icelandic sagas. Every saga containing detailed account on atgeir usage allowing to define the nature of the blow was used as a source.

\begin{tabular}{|l|c|c|c|c|c|}
\hline \multicolumn{1}{|c|}{ Source } & Thrust (total) & Thrust and lift & Cut & Throw & $\begin{array}{c}\text { (Thrust + throw) / } \\
\text { total }\end{array}$ \\
\hline $\begin{array}{l}\text { Legendary } \\
\text { sagas }\end{array}$ & 11 & 2 & 4 & 1 & $75 \%$ \\
\hline $\begin{array}{l}\text { Sagas of } \\
\text { Icelanders }\end{array}$ & 14 & 3 & 1 & 3 & $94.44 \%$ \\
\hline
\end{tabular}

Table 1: Statistics of using an atgeir in combat.

In $75 \%$ of cases described in the legendary sagas and in about $95 \%$ of cases in the sagas of Icelanders the atgeir is used like a spear: for thrusting or throwing. Therefore, the atgeir is indeed not a halberd and not a bill, but a specialised thrusting weapon with an additional ability to hew.

It has to be admitted that the spear is the thing that comes closest to the features of the atgeir. This point of view is typical among modern researchers of the subject. The only 
difficulty is that the atgeir was never called a spear, although the sagas mention spears suitable for hewing and "huge spears".

The problem is the one of classification. Apparently the Vikings used different criterias to classify their pole-weapons than the researchers do. Every item that looks like a spearhead is identified by archeologists as a spear. Though according to the sagas, some of them are not spears, but atgeirs. Therefore we need to find the key features of the atgeir to distinguish it from the spears.

The next part of the paper attempts this theoretical reconstruction.

\section{AN ATTEMPT AT RECONSTRUCTION OF ATGEIR BASED ON OLD ICELANDIC WRITTEN SOURCES}

Researchers have made different and at times contradictory assumptions regarding the atgeir appearance. Hjalmar Falk suggests that it had a stout shaft and a long narrow blade, to correspond to its penetrating ability. ${ }^{8}$ However, the hypothesis about the blade being wide is more popular because a narrow blade does not correspond to the cutting capability of the atgeir. Also it is often assumed that the atgeir had special parts ('wings') for limiting penetration depth. ${ }^{?}$

Because of the inconsistency and lack of detail in the previous assumptions, many of which in our opinion do not correspond to the information contained in original sources, it seems reasonable to attempt the reconstruction of the atgeir from scratch. As a result we should obtain some key requirements to the form of the blade of this weapon. As for the length of the shaft we suggest it not a valuable criterion for classification because it easily could be adjusted according to individual needs.

As the atgeir was so much a spear-like weapon that skalds freely used its name as a beiti for a spear, we must first understand what were its differences from the spear.

The hewing capability is often seen as such a key distinction. But we find it difficult to agree because sagas do sometimes mention spears capable of hewing. There even existed a particular kind of a spear called böggspjót (from böggva - "to hew" and spjót - "spear") whose name itself suggests that it could be used for hewing. Although the suggestion that the atgeir and bögsspjot are the same weapon is common ${ }^{10}$ we consider it incorrect. In that case nothing would prevent the saga authors from using the word spjot as a synonym for the atgeir, but it is never observed throughout the available Old Icelandic sources.

It can be seen from the sagas that many things done with the atgeir could also be accomplished using a spear. Not only such rather common things as to pierce a shield and the arm. A spear could split a shield: "As soon as they met Thorhall thrust at his

8 Falk Altnordische Waffenkunde, p.82

9 Orkisz, Pole-weapons in the Sagas of Icelanders, p.191

10 Orkisz, Pole-weapons in the Sagas of Icelanders, p.191, Cleasby, Vigfusson, An IcelandicEnglish Dictionary, p.30 
shield with the spear; the shield split apart and the spear pierced him through so that the spearhead came out between the shoulder blades" (App. 29). It could also go through human body: "Audolf the Norwegian took a spear and threw it at Gunnar. Gunnar took the spear in the air and threw it back. It went through the shield, the Norwegian and went into the ground" (App. 30).

Therefore at least some spears were equal to the atgeir by penetrating ability. The only thing that is never mentioned with regards to a spear and is only mentioned with regards to the atgeir is lifting the opponent into the air. This can be viewed as the most characteristic feature of the atgeir.

The above-mentioned technique has led some of the researchers to suggest that the atgeir had a kind of a stopper that did not allow the pierced body to slide down along the shaft. The 'wings' that can often be seen on the Viking Age spears could act as such stoppers.

In our opinion such a feature is not obligatory. It is not necessary to lift an opponent over the head in order to hurl him to the side - just lifting them off the ground should be enough. The small angle in addition to the wide blade would not create the conditions for the body to slide down. The above example of Gunnar's atgeir going smoothly through the body and then into the ground proves that it had no parts for limiting overpenetration.

In our view what the lifting technique indicates is primarily the strength of a shaft. It is generally believed that spear shafts were strong, but as illustrated by the sagas, they often broke when the power of the thrust was too big or under the weight of a man jumping on it. On the contrary, atgeir wielders were clearly not worried about burdening it with weight of a human. The Njáls saga confirms it by describing the way Gunnar sometimes mounted the horse. Therefore the first feature that could be attributed to the atgeir is a thicker shaft than that of a common spear and, consequently, a bigger socket diameter. Most Viking spears had a socket diameter of $2-3 \mathrm{~cm}$ so we can assume that the atgeir had more than $3 \mathrm{~cm}$.

The strength of the shaft, as well as its weight, is in quadratic dependence from its diameter. Therefore even a small increase in a shaft diameter results in a considerable increase in its weight. For example, a shaft with diameter equal to $3.5 \mathrm{~cm}$ weighs almost twice as much as the shaft with $2.5 \mathrm{~cm}$ diameter. So this assumption comes in line with such properties of the atgeir as its heaviness and durability.

Next we should consider the form of a blade to allow both thrusting and hewing. It is obvious that narrow blades and leaf-shaped blades are good for thrusting, but not for hewing. The long-edged cutting weapon of the Vikings (sword, sax) had a straight wide blade slightly rounded to the point. The blade should be of considerable length. The atgeir blade should also be rather thick in order to be able to split shields. The atgeir's head is likely to be symmetrical which is good both for throwing (spear) and for hewing (sword).

As for the length of the blade it should respect the limitations imposed by the weapon type. A pole-weapon should be balanced in such a way as for the warrior to be able to hold it at a good distance from the blade, in order to use the advantage of a long shaft. Narrow spearheads are usually longer than the wide ones meaning that their weight is roughly the same. Therefore the head of the atgeir that we have supposed earlier to be 
heavy, could not be much longer than a heavy spearhead. At the same time it should have a long cutting blade. This could be achieved by making its socket shorter.

A thick shaft would be another factor to help balance the atgeir in the manner of a spear. On the whole the massive blade and the thick shaft make the atgeir heavier than a regular spear, which is consistent with the information in Old Icelandic sources. Still the length of a shaft should be comparable to that of a regular spear, to suit a fighter on foot.

To sum up, the atgeir is not bigger than a spear by its total length, but is more massive. The form and proportions of its head should differ considerably from all known spearheads.

The below list summarises the proposed key physical features of the atgeir's head:

1. A greater socket diameter than a spear usually had.

2. The short socket.

3. A long, wide (probably widening towards the socket), symmetrical blade with straight edges.

Also, according to Old Icelandic sources:

1. The atgeir existed in Scandinavia in the Age of Sagas, i.e. in the $10^{\text {th }}-11^{\text {th }}$ centuries AD.

2. It was widespread on the Eastern Way: Sweden, the Baltic Sea region and Gardariki.

3. It was rare in Iceland.

It should be taken into account that the physical features proposed above are speculative, but two things could be asserted after analysis of the sources:

1. The atgeir is a pole-weapon looking much like a spear, given its use in combat and the use of its name in scaldic poetry.

2. The atgeir is not a spear, but a separate type of weapon, because the term "spear" (spjót) is never used as a synonym for it. This implies certain radical differences from all the variety of spears of the Viking Age.

\section{ARCHEOLOGICAL RECORDS ANALYSIS}

As it was shown previously in this paper, the atgeir was a rare but familiar weapon. Therefore its quantities should not be so small as not to leave a trace in archeological data. As we will search for the atgeir among the spearheads belonging to the Viking Age, the obvious choice is a widely recognised classification of the Viking spears developed by J.Petersen. Several spearhead types by Petersen are suggested by nowaday researchers as candidates for the atgeir, typically B, C, D, F, G, $\mathrm{H}^{11}$. This list constitutes almost a half of

11 Orkisz, Pole-weapons in the Sagas of Icelanders, p.191, McMullen, Góð vopn á sjó og landi, p. 27 
all Petersen speartypes. We will try to be more specific taking into account the proposed features of the atgeir listed in chapter VIII.

As J.Petersen's typology is not too extensive a good option can be found with ease: this is type $\mathrm{G}-$ a quite large spearhead with the wide straight-edged blade widening towards the socket (Fig.4). It differs from most other types by a short socket that has a slightly greater diameter. The spear with such a spearhead should definitely have a thicker shaft. Because of the shorter socket, the effective length of the blade edge is longer than in other spearheads of a similar total length. J.Petersen also mentions that a common feature of specimens of this type is the socket partly protruding into the blade.

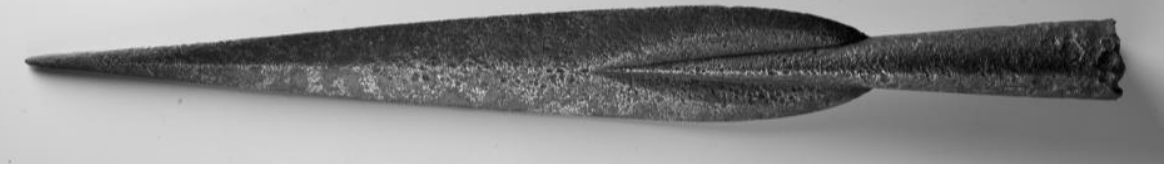

Figure 4: Petersen type G spearhead from online collection of Kulturbistorisk museum, $\mathrm{UiO}$ (Norway), museum number C17631, photographer Helgeland, Kirsten. License: CC BY-SA 4.0

Considering the above, type $\mathrm{G}$ is a good candidate to the role of the atgeir corresponding to our theoretical reconstruction based on the sagas. It differs considerably in its appearance from other types, except type $H$ which is similar to $G$ in its form and size and therefore also could be viewed as a possible candidate. Besides, Petersen typology also has type D2 which differs from type $G$ only by having wings. In other spearhead typologies it is considered a subtype of G. Further in this paper we will view G and D2 as a single "type G" with some limitations which will be discussed later.

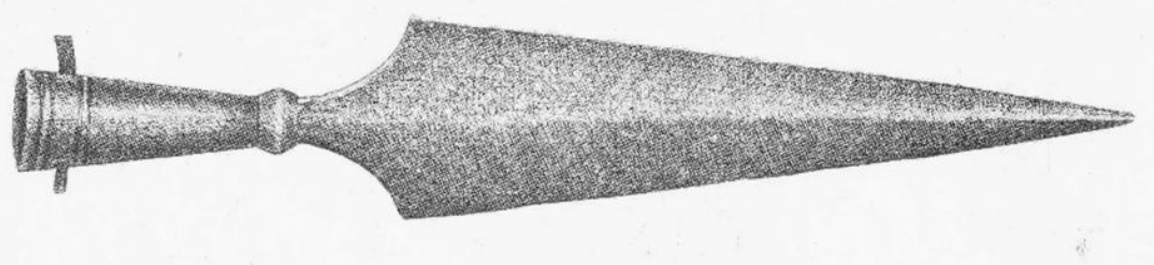

Figure 5: Petersen type H spearhead from J.Petersen, De norske vikingesverd. License: CCO.

J.Petersen determined the period of existence of types $\mathrm{G}$ and $\mathrm{H}$ as the 10 th-11th centuries $\mathrm{AD},{ }^{12}$ i.e. the so called Age of Sagas.

The complication is that we expected the atgeir to be a heavy long-bladed weapon while type $G$ spearheads mostly have moderate length and one type $\mathrm{H}$ found in Iceland is not longer than $20 \mathrm{~cm}$. 
In addition, plenty of big spearheads having blades with cutting capabilities are found among other Petersen types. For example the spearhead shown in Fig.6 also fits to the atgeir requirements.

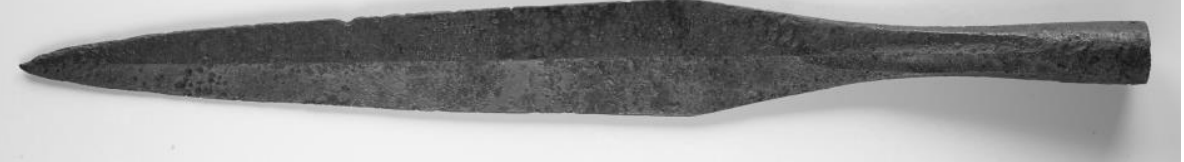

Figure 6: Viking spearbead (probable Petersen type A) from online collection of Kulturbistorisk museum, UiO (Norway), museum number C19810, photographer Helgeland,

Kirsten. License: CC BY-SA 4.0

Here we should state our opinion that thinking that the atgeir is just a type of a spear is a misconception. If we assume that it is not a spear but a separate type of a pole-weapon then it should differ considerably from spears. The only type meeting this requirement is type G.

Let us look more carefully at the construction of the spearhead in the place of transition from the socket to the blade. This is the weakest part of every spear. Spears commonly broke "above the socket" and it is clear why if we look at the slender sockets of the viking spears which diminish even more towards the blade. The supposed atgeirs for their part have this piece implemented in a different way. There is no transition at all and the bottom part of the blade is lowered around the socket (Fig.7). We assume that this is done so to strengthen the blade-to-socket connection. No other spearhead among Petersen speartypes, including type $\mathrm{H}$, is constructed in this way and as it was illustrated earlier in the paper the strength is one of the important properties of the atgeir according to the sagas.
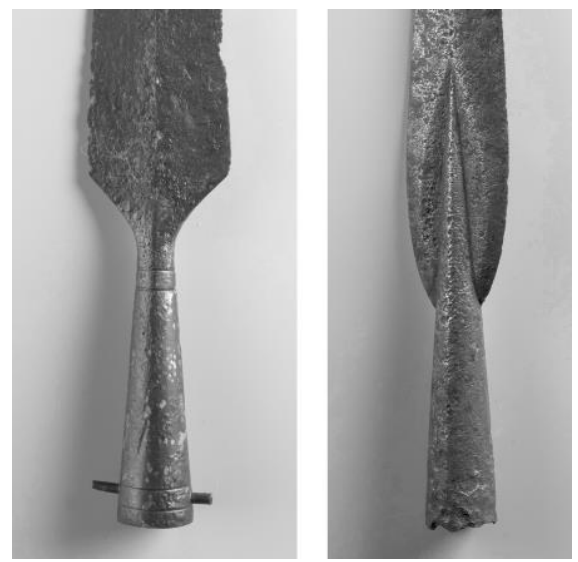

Figure 7: Types of blade-to-socket connections characteristic to the most of Viking spears (on the left) and to Petersen type $G$ spears (on the right). The items shown are from online collection of Kulturbistorisk museum, UiO (Norway), museum number C26494b and C17631, photographer Helgeland, Kirsten. License: CC BY-SA 4.0 
By the construction of the blade-socket connection Petersen type $G$ is unique among all Viking speartypes which widely differ in sizes and forms, but have the same constructive plan. Type $G$, the supposed atgeir, stands aside.

Moreover, the socket built into the blade definitely requires a special technology.

In most spears the socket is separated from the blade. The transition from the socket to the blade starts above the socket. Some narrow spearheads (for example, type E) have a very smooth, barely visible transition while in others it is clearly visible. But in all cases the blade and the socket were made in and this is true for all Viking spears except type G. These spearheads have sockets built into the blade, thus the blade and the socket had to be manufactured simultaneously. Therefore type $G$ spearheads could not be produced by traditional spear-making technology.

In our opinion this technological uniqueness is the strongest argument in favor of identifying the type $G$ spearhead as the atgeir - a spear-like pole-weapon that was not a spear. It is the radically different construction that determines that the type $G$ spearheads are non-spears. The shape of the blade (which is known to differ considerably among the viking spearheads), the blade-socket proportion and the socket diameter cannot be considered the decisive attributes although all of those helped us in the search. Considered together with its other features described below the type $G$ is the most probable candidate for the role of the atgeir.

Petersen type G spearheads also satisfy to other characteristics of the atgeir found in the sagas. The archeological finds of this type belong to the $10^{\text {th }}-11^{\text {th }}$ centuries, which is the time when the events of the Sagas of Icelanders take place and when skaldic poetry was created, both sources referencing the atgeir. The majority of the finds originate from the Baltic Sea Region and Sweden, which was the Eastern Way of the vikings. At the same time, in Iceland only 3 (three) of 81 discovered Viking Age spears are attributed to type $\mathrm{G}^{13}$, the fact that fully corresponds to the "rare but familiar" pattern observed from Icelandic sagas.

Thus, from searching for a heavy thrusting and cutting weapon we came to the understanding of the technological distinction. This result seems to correspond to the saga material as well to the meaning of the term "weapon type". The size of the atgeir was not its determining feature. Archeological data shows that just as every other contemporary weapon type (probably except rather uniform Frankish swords) it could be heavy or light, big or moderate. It is the specific construction that makes it an atgeir.

\section{SPJÓT IS NOT A SPEAR: NOTES ON SPEARHEADS CLASSIFICATION AND TERMINOLOGY}

As described above, the search for the atgeir among archeological data has led us to an unexpected but important conclusion: although existing viking spear typologies mostly consist of several types, all known Viking Age spearheads can be divided only in two main

${ }^{13}$ Fedir Androshchuk, Ragnheiður Traustadóttir, A Viking Age spearhead from Kolkuós, p.6 
groups according to the way their blade is connected to the socket. The specimens of the first group have the blade formed on top of the socket, while the second group have the socket partly built into the blade. The vast majority of known viking spearheads of different shapes and sizes belong to the first group. The second group is rather small and consists only of Petersen's type G spearheads.

This division is fully in line with the classification of pole-weapons implied by Old Icelandic sources. The first (larger) group corresponds to the spears (spjot $)$ and the second one to the atgeir. Fig. 8 shows schematic drawing of these types.

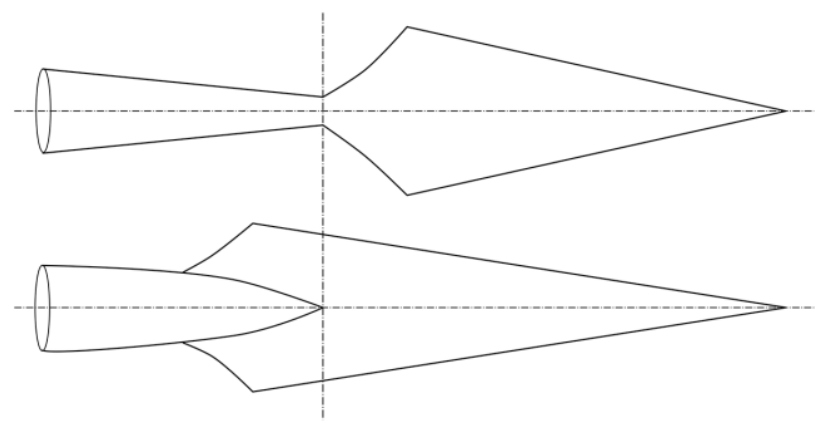

Figure 8: Schematic drawing of two main Viking pole-weapon types: spjót (on the top) and atgeirr (on the bottom).

But in order to accept this classification we have to admit that the term "spear" widely used to translate the Old Icelandic term spjót does not in fact match its meaning. A spear is generally understood as a pole-weapon with a long narrow symmetrical double-edged blade, mounted on the shaft by means of a socket. All found viking age pole-weapons satisfy to this description, therefore it is not possible to find among them another type known from sagas (atgeir). Many years of the unsuccessful search for the atgeir prove this.

Still, the classification contemporary to the Vikings could be easily recreated taking the construction of the weapon as the main criterion. Then the terms known from the sagas take the following meanings: spjót ("spear") - a pole-weapon with its blade on top of the socket and atgeirr ("atgeir") - a pole-weapon with the blade partly or fully formed around the socket. To sum up, "the Viking spear" (spjót) is a more narrow term than the general concept of the spear.

The spjot-type construction lasted well after the Viking Age and became the only construction for such type polearms. Consequently this term lost its original meaning which it probably had in all Germanic languages. The construction of the atgeir was forgotten along with its name and now it is known to us only via such a unique source as Old Icelandic sagas. 


\section{AN OVERVIEW OF ATGEIR CONSTRUCTION BASED ON ARCHEOLOGICAL FINDS}

This chapter looks more closely at some of the known specimens of the supposed atgeir.

The most characteristic feature of all specimens considered is the short socket that looks even shorter because of being built to some extent into the blade. "Short thick socket" is the first thing Jan Petersen says about type $G$ spearheads ${ }^{14}$. The diameter of the socket is usually wider than that observed of spears of equal length. The level to which the socket is built into the blade varies from rather small to considerable.

It should be noted that the socket built into the blade is the sole criterion proposed for classifying a viking spearhead as an atgeir. Petersen's typology is based on other principles so it is possible that not all type $G$ spearheads by Petersen are atgeirs.

The shape of the atgeir's blade resembles a sword blade though it narrows more strongly to the point. Due to their special construction atgeirs have a longer effective edge length compared to spearheads (spjót) of equal length, which provides for a good cutting capability. As for stoppers ('wings'), most atgeirs do not have them, however there are some specimens that do.

The majority of the supposed atgeirs have wide blades, but some are rather narrow. The lower parts of the blade where it connects to the socket can be straight, rounded or concaved. Therefore atgeirs, like spears (spjót), could be divided in subgroups by their blade form.

The archeological finds that could be identified as atgeirs mostly come from Finland and the Baltic Region. These specimens commonly have sockets ornated with silver and gold, a moderate length (about $40 \mathrm{~cm}$ ) and rather thin blades. On the other side the specimens found in Norway like the one shown in Fig.4 are bigger and thicker and have little or no decorations.

The mostly moderate size of the known atgeirs could be disappointing for those inclined to see it as the heavy weapon of Njáls saga and some others. Still, it is consistent with information from other sagas of Icelanders (those do not stress the big size of the atgeir) as well with the fact that a heavy weapon was not comfortable to use for most warriors.

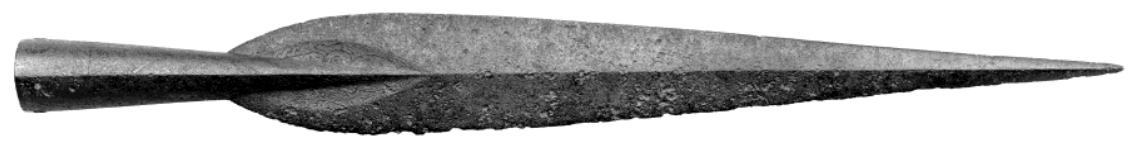

Figure 9: A big atgeir on display in University Museum of Bergen. Photo from online collection of University Museum of Bergen. Museum number B6711. License: CC BY-NC-ND 3.0

14 Petersen J., De norske vikingesverd, p.29 
Bigger atgeirs also exist, one of which is on display in University Museum of Bergen, shown in Fig.9. This item was discovered in Norway. Its length is $51.5 \mathrm{~cm}$ and the width of the widest part is $5.5 \mathrm{~cm}$. Estimated outer socket diameter is about $3.5 \mathrm{~cm}$.

The blade of this atgeir has a very universal shape. Long and tapering to the point it resembles a pike and should be capable of piercing mailshirts. Besides, it has a long straight cutting edge. A closer look at this powerful yet elegant blade reveals an unusual and stylish decoration - a fine engraving on the socket and the lower part of the blade. By the style of this decoration it is attributed to 600-800 AD. At the same time, similar specimens without decorations (Fig.4) are attributed to the Viking Age. Given the size, shape and quality of this specimen (Fig.9) it is a very good candidate for the role of the heavy atgeir, therefore it could be seen as the most probable prototype of the famous atgeir described in Njáls saga.

At this point it is evident that Old Icelandic sources describe a heavy atgeir. An ordinary atgeir did not merit description thus it is mentioned in sagas only in passing. But a heavy atgeir seems to be a very special weapon. Its blade equalled half a sword or a good sax in length, with a good cutting capability, and the durable thick shaft could easily withstand the weight of a human. Not only was the heavy atgeir a multipurpose weapon it was also a very reliable one.

So the heavy atgeir as depicted in the sagas is truly a "king of weapons" and a natural choice for the mighty warriors of the Legendary sagas. And when Konungs skuggsjá mentions "good atgeirs" (godir atgeirar), probably it speaks about heavy atgeirs.

Given the archological findings of proposed atgeirs to be attributed to $10^{\text {th }}-11^{\text {th }}$ centuries $\mathrm{AD}$, it was a contemporary weapon for saga characters. Thus, references to it in sagas should not be seen as anachronisms. Regarding the reference in Konungs skuggsjá (1 $3^{\text {th }}$ century) it also was in use at the times when sagas were written, so it was known to saga authors too.

Let us also consider archeological finds from beyond the limits of the Viking Age. The bronze spearhead attributed to the Bronze Age (see Fig.10) suggests that the term atgeirr (atiger, etger, etc.) could indeed be older than the Viking Age (and probably older than the term spjót). Its form is common to European bronze spearheads, probably due to lower hardness of bronze compared to steel. Later in time, having disposed of limits imposed by the material the atgeir evolved into a more spear-like shape. 


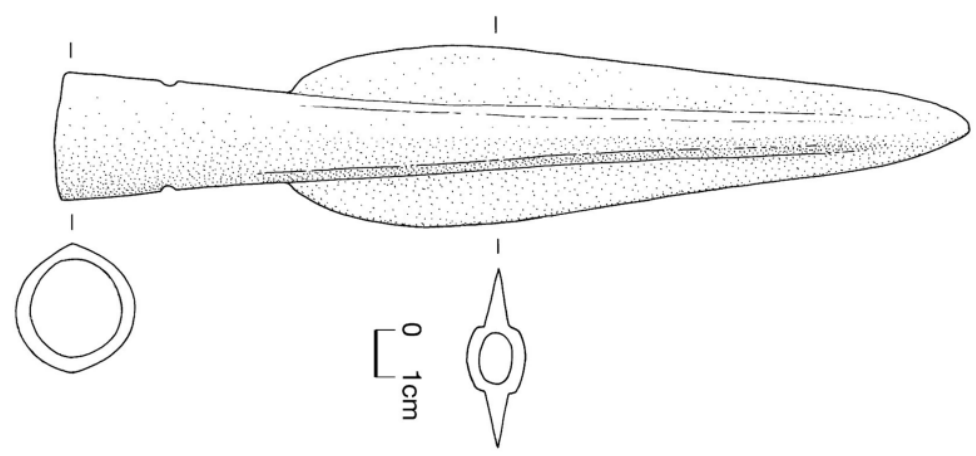

Figure 10: Bronze spearhead, museum number WG.1108. Trustees of the British Museum.

License: CC BY-NC-SA 4.0

On the other hand, when looking at the medieval halberd (Fig.11) and the way its shaft protrudes far into the blade it seems understandable why this weapon could also be called atgeir in the Middle Ages Iceland.

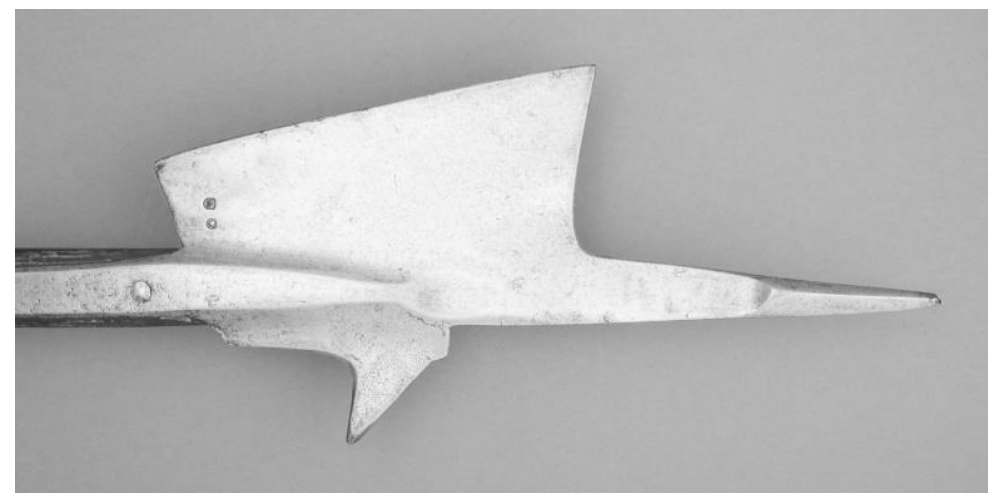

Figure 11: A 15th century halberd from online collection of the Metropolitan Museum of Art. Accession number: 42.50.21. License: CCO 1.0

In conclusion, the atgeir has long been on the radar of archeologists and historians, as shown by the examples earlier in this paper. But the lack of definitive classification criteria prevented it from being confidently identified among the mass of viking spearheads. Such a criterion restored by the material of Old Icelandic sagas is proposed in this paper.

\section{FURTHER RESEARCH}

The classification of pole-weapons by the construction type described in this paper seems to be natural. It is surprising that all existing scientific typologies of the Viking spears rely on other criteria. In J.Petersen typology atgeirs are placed into two separate types: $G$ and D2. In Thålin-Bergman's typology types G/D2 are united with type $H$ which resembles 
them in the shape but has a different construction. In B.Solberg's typology proposed atgeirs together with type $\mathrm{H}$ spearheads are put in subtypes of the two classes.

As it was shown above, the sole criterion to classify a spearhead as an atgeir is the way its blade is connected to the socket while Petersen's typology is based on other principles. Therefore, if not all type $G$ spearheads satisfy to the above requirement, not all of them are atgeirs, despite the similarity of shape. Hence, the need of a different typology that would correspond to the one used in Viking Age and preserved in Old Icelandic sources is evident. This research could be the first step on this way.

The next step would be to research the specimens which are supposedly identified as atgeirs. These are mostly Petersen types G spearheads. It would be very interesting to collect data on their size, weight and quality because the heavy atgeir of Icelandic sagas, presumably a prestigious and valuable weapon, implies high quality. Some practical tests could demonstrate if the construction of the atgeir really has advantages in durability and universality as it is implied by the sagas.

The would-be atgeirs need to be classified by size and shape as well as the locations where they were manufactured. It would also be useful to understand the differences between the two main classes - heavy ones without or with little decoration and decorated ones of moderate size. Petersen type $G$ spearheads have not so far received much scientific attention and probably the time has come to rectify this.

Finally, a fascinating area for research is recreating the technology of making an atgeir which seems to be more complicated than that of a spear. Probably this factor, together with a tendency for the narrower and lighter spearheads towards the end of the Viking Age, has played its part in the disappearance of this technology while spears continued to be made for many centuries after.

\section{CONCLUSIONS}

For more than a century historians and researchers of the Old Norse literature struggled to determine what the unknown Viking weapon called atgeir was. Modern science proved such suggestions as a halberd or a bill to be wrong but the range of proposed candidates among viking spearheads was too wide, constituting almost a half of all Petersen speartypes. The goal of this paper was to define the best candidate.

In order to achieve this, nearly all available Old Icelandic written sources referencing the term atgeirr were analysed: the Legendary sagas, the sagas of Icelanders and skaldic poetry. In this analysis not only was it attempted to figure out the atgeir's shape, size and the ways it was used in battles, but also the chronological and geographical context of its references was considered.

It was concluded that all sources consistently describe the atgeir as a rare but familiar weapon, spear-like in shape, durable, suitable for hewing and mainly distributed on the Eastern Way (Austrvegr). It was also confirmed that sagas never interchange the term atgeirr with the term spjot (spear), which indicates that the atgeir should differ considerably from all the known varieties of the viking spears. 
After comparing the properties of atgeir found in Old Icelandic sources with archeological record of the Viking Age the suggestion was put forward that the atgeir is defined not by the shape or size of the blade (which are the main criteria used in most modern Viking spearhead typologies) but by the specific construction of this weapon, when the blade is formed partly of fully around the socket and not on top of it, as in the majority of the viking spearheads. Such a construction is characteristic for Petersen type $\mathrm{G}$ spearheads. This constructive and technological difference could be seen as a sufficient criterion to distinguish these specimens as a separate weapon type. By Petersen typology type $G$ spearheads existed in Scandinavia in the $10^{\text {th }}-11^{\text {th }}$ centuries (so called Age of Sagas) and are mostly found in Sweden, the Baltic Sea region and Finland. In summary, the spearheads of this type are the most possible candidates for the role of atgeir.

Finally, it should be noted the definition of an item of material culture (though it was a long-time enigma) was not the only result of this research. A rather unexpected conclusion turned up that the term "spear", familiar to everyone and seemingly not requiring explanations, had a different meaning in the Viking Age. From the point of view of the Viking Age people the atgeir and the spear (spjót) were defined not by the shape but by construction, which is a deeper notion. It should not come as a surprise though, as people back then were more close to the process of creating things than most of us now are.

Definition of the atgeir, a spear-like weapon that is not a spear, brings us one step closer to understanding the culture and the mindset of the people who lived a thousand years ago, which I believe to be the ultimate goal of historical research.

\section{List of abbreviations}

MHG. $=$ Middle High German.

OFries. $=$ Old Friesian.

OHG. = Old High German.

\section{Acknowledgements}

First of all I want to thank my sister Valeria for her invaluable help in translating this paper into English. Many thanks to Mrs. Brita Hope from University Museum of Bergen who helped me with the archeological part of this research. I would also like to thank Mr. Jan Orkizc and Mr. William R. Short for inspiration and informative discussion on the topics regarding this paper.

\section{BIBLIOGRAPHY}

\section{XI.1. Primary sources}

Anonymous, Illuga saga Tagldarbana, Íslendinga sögur, Guðni Jónsson bjó til prentunar, <http://heimskringla.no/wiki/Illuga_saga_Tagldarbana>, accessed 14 June 2018 
Anonymous, Göngu-Hrólfs saga, Fornaldarsögur Norðurlanda, Guðni Jónsson og Bjarni Vilhjálmsson sáu um útgáfuna, <http://heimskringla.no/wiki/G\%C3\%B6ngu$\mathrm{Hr} \% \mathrm{C} 3 \%$ B3lfs_saga $>$, accessed 14 June 2018

Anonymous, Gautreks saga, Fornaldarsögur Norðurlanda, Guðni Jónsson og Bjarni Vilhjálmsson sáu um útgáfuna, <http://heimskringla.no/wiki/Gautreks_saga>, accessed 14 June 2018

Anonymous, Bósa saga ok Herrauds, Fornaldarsögur Norðurlanda, Guðni Jónsson og Bjarni Vilhjálmsson sáu um útgáfuna, $<$ http://heimskringla.no/wiki/B $\%$ C3\%B3sa saga ok_Herrau $\% \mathrm{C} 3 \% \mathrm{~B} 0 \mathrm{~s}>$, accessed 14 June 2018

Anonymous, Hálfdanar saga Eysteinssonar, Fornaldarsögur Norðurlanda, Guðni Jónsson og Bjarni Vilhjálmsson sáu um útgáfuna,

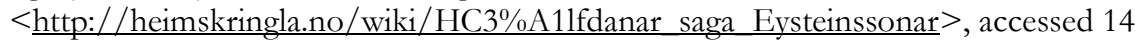
June 2018

Anonymous, Hjálmpés saga ok Ölvis, Fornaldarsögur Norðurlanda, Guðni Jónsson og Bjarni Vilhjálmsson sáu um útgáfuna, $<$ http://heimskringla.no/wiki/Hj\%C3\%A1lm\%C3\%BE\%C3\%A $\%$ s saga ok $\% \mathrm{C} 3$ \%96lvis >, accessed 14 June 2018

Anonymous, Völsunga saga, Fornaldarsögur Norðurlanda, Guðni Jónsson og Bjarni Vilhjálmsson sáu um útgáfuna, < http://heimskringla.no/wiki/V\%C3\%B6lsunga_saga>, accessed 14 June 2018

Anonymous, Dáttr Porleifs jarlaskálds, Fornmanna Sögur eptir gömlum handritum. Driðja bindi. Útgefnar að tilhlutun hins Norræna Fornfræða Félags, Kaupmannahöfn, 1826, $<$ http://heimskringla.no/wiki/\%C3\%9E \%C 3\%A1ttr \%C3\%9Eorleifs jarlask $\% \mathrm{C} 3$ \%A1lds $>$, accessed 14 June 2018

Anonymous, Eyrbyggja saga, Íslendinga sögur, Guðni Jónsson bjó til prentunar, < http://heimskringla.no/wiki/Eyrbyggja saga>, accessed 14 June 2018>

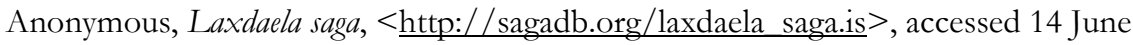
2018

Anonymous, Landnámabók Annar bluti, Guðni Jónsson bjó til prentunar, $<$ http://heimskringla.no/wiki/Landn $\% \mathrm{C} 3 \% \mathrm{~A} 1 \mathrm{mab} \% \mathrm{C} 3 \% \mathrm{~B} 3 \mathrm{k}$ - Annar_hluti $>$, accessed 14 June 2018

Anonymous, Bjarnar saga Hitdalakappa, Íslendinga sögur, Guðni Jónsson bjó til prentunar, < http://heimskringla.no/wiki/Bjarnar saga $\mathrm{H} \% \mathrm{C} 3 \% \mathrm{ADtd} \% \mathrm{C} 3 \%$ A6lakappa $>$, accessed 14 June 2018

Anonymous, Brennu-Njáls saga, $<$ https://www.snerpa.is/net/isl/njala.htm

$>$, accessed 14 June 2018

Anonymous, Egils saga Skalla-Grímssonar, Íslendinga sögur, Guðni Jónsson bjó til prentunar, $<$ http://heimskringla.no/wiki/Egils saga Skalla-Gr\%C3\%ADmssonar $>$, accessed 14 June 2018 
Keyser, Rudolph; Munch, Peter A.; Unger, Carl R., eds. Speculum Regale, Konungs Skuggsjá, Konge-Speilet. Oslo: Carl C. Werner \& Co., 1848,

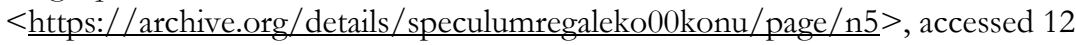
September 2018.

\section{XI.2. Secondary literature}

Cleasby, Richard and Gudbrand Vigfusson, An Icelandic-English Dictionary (Oxford, 1874).

Keller, May L., The Anglo-Saxon Weapon Names Treated Etymologically and Archaologically (Heidelberg: Carl Winter's Universitätsbuchhandlung, 1906).

Orkisz, Jan, "Pole-weapons in the Sagas of Icelanders: a comparison of literary and archaeological sources", Acta Periodica Duellatorum 4/1 (2016), 177-212.

Petersen, Jan, De norske vikingesverd. En typologisk-kronologisk studie overvikingatidens vaaben (Kristiania : J. Dybwad, 1919).

A Viking Age spearbead from Kolkuós. Framvinduskýrsla 6 - 2004. Fedir Androshchuk. Ragnheiður Traustadóttir.

K. James McMullen, Gód vopn á sjó og landi: An examination of the atgeirr and kesja in Old Norse literature and Scandinavian archaeology, unpublished Phd thesis, Háskoli Íslands Íslensku- og menningardeild Medieval Icelandic Studies, 2014.

Friðriksson, Adolf, Hildur Gestsdóttir, Astrid Daxböck and Guðrún AldaGísladóttir, Hringsdalur i Arnarfiroti - Fornleifarannsókn 2006, FS413-06441, Reykjavík, 2010.

Falk, Hjalmar, Altnordische Waffenkunde (Kristiania: Dybwad i Komm., 1914).

The Story of Burnt Njal, 1861 translation into English by George W. DaSent, <http://sagadb.org/brennu-njals_saga.en>, accessed 19 August 2018.

Short, William R., Viking Age Arms and Armor: Viking Spear, $<$ http://www.hurstwic.com/history/articles/manufacturing/text/viking_spear.ht>, accessed 10 July 2018.

Short, William R., A Listing of References to Arms and Armor in the Sagas of Icelanders, $<$ http://www.hurstwic.com/library/arms_in_sagas $>$, and references therein, accessed 15 July 2018.

The Viking Age Compendium, Spears found in Britain, Website $<$ http://www.vikingage.org/wiki/wiki/Spears_found_in_Britain>, accessed 10 September 2018. 


\section{APPENDIX}

Below the citations from Icelandic Sagas used in analysis are provided:

1. Völsunga saga, ch. XI

Ok er orrosta hafdi stadit um hríd, pá kom madr í bardagann med sidan bött ok beklu blá. Hann hafoi eitt anga ok geir í hendi. Dessi madr kom á mót Sigmundi konungi ok. brá upp geirinum fyrir hann. Ok er Sigmundr konungr hjó fast, kom sverdit i geirinn ok brast i sundr i tvá bluti.

2. Sturlaugs saga starfsama, ch. XVI.

Dá sér Sturlaugr, at bún muni fá prifit í fatr honum, ok vill eigi pess bida ok bleypr ór bátinum utan ok á einn stein ok leggr at henni med atgeirnum, svá at stód i gegnum hana.

3. Illuga saga Tagldarbana, ch. 11

En pat er frá Illuga at segja, at pegar hann kemr inn, tvíhendir hann atgeirinn á Tjösni midjan, ok gekek i gegnum bann.

4. Illuga saga Tagldarbana, ch. 11

...kemr Illugi á hann lagi ok. leggr atgeirnum i gegnum jötuninn svo sterkliga, at hann brotnar i sundr upp vid falinn.

5. Göngu-Hrólfs saga, ch. VIII

Hann [Tryggvi] átti sér fóstbródur, er Vazi hét. Hann var ok it mesta tröllmenni, baði sakir vaxtar ok sterkleika.

6. Göngu-Hrólfs saga, ch. VIII

Vazi haffi atgeir i hendi, en Tryggvi öxi. Hrólfr fór mót Vaza, ok lagdi huárr til annars. Atgeirrinn kom i skjöld Hrólfs, ok klofnađi hann allr i sundr, en Hrólfr varð ekeki sárr.

7. Göngu-Hrólfs saga, ch. XVIII

Hann var par attadr at módurkyni, en föjurkyni i Hólmgardariki... Hann var it mesta tröllmenni fyrir sakir afls ok vaxtar. Y firlitr hans var eptir nafni hans.

8. Göngu-Hrólfs saga, ch. XVIII

Sóti hafdi atgeir at vega með ok gerdi ýmist hann hjó eða lagði.

9. Göngu-Hrólfs saga, ch. XVIII

Sóti hjó tveim böndum til Hrólfs. Höggit kom á midjan skjöldinn, ok par i sundr, ok bestinn fyrir framan bóguna, svá at i jörou nam stadar...Sóti bjó til Hrólfs, en bann veik sér undan, ok sökk atgeirrinn i jördina allt upp at böndum honum. 
10. Gautreks saga, ch. VI

Vikarr konungr fór med her sinn i Vik austr ok geke á land austan fjardar ok herjadi upp á Gautland ok vann par mikit bervirki. En er hann kom upp i Vani, pá kom par á móti honum konungr sá, er Sisarr hét. Hann var austan ór Kanugardi. Hann var kappi mikill ok hafdi lid mikit.

11. Gautreks saga, ch. VI

Oká sídu

sverdi beitti

mér öflugr

fyrir mjödm ofan,

en i adra

atgeir lagdi

köldum broddi,

svát á kafi yddi.

12. Bósa saga ok Herrauðs, ch. XIV

Herraudr sneri nú i móti Siggeiri ok leggr til hans med atgeir, svá at geke i gegnum skjöldinn, en Siggeirr snaradi svá hart skjöldinn, at Herraudi vard lauss atgeirrinn...

13. Hálfdanar saga Eysteinssonar, ch. XIII

Hrafnkell skaut tveimr kesjum senn at inum mikla manni, en hann tók bádar á lopti ok skaut aptr ok hafdi mann fyrir hvárri. Sidan lagdi hann med atgeir til Hrafnkels i gegnum skejöldinn ok báda handleggina ok vá hann upp ok kastadi bonum út á sjóinn.

14. Hjálmpés saga ok Ölvis, ch. V

Geke Tóki röskliga fram ok vá til beggja handa. Hann hafoi stóran arngeir ok sterkan i hendi. Drap hann á litilli stundu prjátigi menn.

15. Hjálmpés saga ok Ölvis, ch. V

Tóki spennir tveim höndum arngeirinn ok leggr i gegnum skejöld Ölvis ok svá i gegnum báda handleggina ok kastar honum i lopt upp ok fleygir honum nidr á piljurnar, svá at hann lá íoviti.

16. Keyser, Speculum Regale:

Blýsteyptir hersporar ok gódir atgeirar eru ok gód vápn á skipi.

17. Páttr Porleifs jarlaskálds, ch. 6

... i pessu bili lagđi Dorgardr atgeirnum á Porleif midjan ok i gegnum hann; 
18. Eyrbyggja saga, ch. 26

Dú skalt fara til Helgafells ok ganga i loft pat, er yfir er útidurum, ok rýma fjalir i gólfinu, svá at pú fáir par lagt atgeiri i gegnum. En pá er Snorri gengr til kamars, pá skaltu leggja atgeirinum i gegnum loftsgólfit i bak. Snorra svá fast, at út gangi um kvidinn, blaup siðdan út á rafrit ok svá ofan fyrir vegginn ok lát náttmyrkrit geta pin.

19. Laxdaela saga, ch. 64

Og i pessi svipan lagði Hardbeinn út atgeiri úr selinu par sem hurdin var brotin. Lagið kom i stálhúfu Dorsteins svarta svo að i enninu nam stadar.

20. Landnámabók Annar hluti, ch. 33

Dá er Dorbjörn vildi lúka aftr virkinu, var hann skotinn ígegnum með atgeiri. Dorbjörn tók atgeirinn ór sárinu ok setti milli herda Jörundi, svá at út kom i brjóstit.

21. Brennu-Njáls saga, ch. 63

Gunnar leggur i móti atgeirinum og kom á Egil midjan. Gunnar vegur hann upp á atgeirinum og kastar honum út á Rangá.

22. Brennu-Njáls saga, ch. 72

Gunnar skaut atgeirinum til hans og kom á skejöldinn og klofnadi hann i tvo hluti en atgeirinn hljóp i gegnum Önund.

23. Brennu-Njáls saga, ch. 54

Skammkell hljóp á bak Gunnari og höggur til hans med mikilli öxi. Gunnar snerist skjött ad honum og lýstur við atgeirinum og kom undir kverk öxinni og hraut hún úr hendi honum út á Rangá. Gunnar leggur i annad sinn atgeirinum og i gegnum Skammkel og vegur hann upp og kastar honum i leirgötuna ad höffinu.

24. Brennu-Njáls saga, ch. 63

Börkur höggur til Gunnars. Gunnar laust við atgeirinum svo bart að sverdið braut úr bendi Berki.

25. Brennu-Njáls saga, ch. 63

Tók hann pá atgeirinn og sverdið og vegur med bádum höndum.

26. Brennu-Njáls saga, ch. 63

Litlu sídar skýtur Gunnar til Barkar atgeirinum og kom á hann midjan og i gegnum bann og nidur i völlinn.

27. Brennu-Njáls saga, ch. 79

Hróaldur leggur til Högna. Högni bjó i sundur spjótskaftid med atgeirinum en rekur atgeirinn i gegnum hann. 
28. Brennu-Njáls saga, ch. 54

Gunnar gengur út og stingur nidur atgeirinum og verpur sér i söđulinn og rídur braut.

29. Brennu-Njáls saga, ch. 145

..og jafnskjótt sem peir fundust lagđi Dórhallur til hans spjótinu og kom i skjöldinn og klofnadi hann i sundur en spjótið bljóp i gegnum hann svo ad oddurinn kom út á milli herdanna.

30. Brennu-Njáls saga, ch. 54

Auðólfur austmaður preif upp spjót og skaut að Gunnari. Gunnar tók á lofti spjótið og skaut aftur pegar og fló i gegnum skjöldinn og austmanninn og nidur i völlinn. 